\title{
BUDGET SYSTEM AND ACCOUNTING IN BUDGETARY INSTITUTIONS
}

\author{
Natalia Koval ${ }^{1}$
}

\begin{abstract}
The purpose of this article is to investigate the budget system, accounting in budgetary institutions and changes that have occurred in budgetary legislation. The content and concepts of the budget system and its accounting are disclosed. Method. Theoretical approaches to determining the mechanisms and discrete components of the state budget system and its transition to the new IBAN international standards system have been developed. The research is based on the use of a systematic approach to the consideration of phenomena in the Treasury system of Ukraine and the budget system, on the fundamental principles of economic theory, systems theory, theory of finance, the theory of international calculations according to IBAN international standards. Results. There is an inseparable link between the Treasury and the budget system and the new legislation governing their activities. Value/originality. It has been determined that the dynamic development of states, regions and communities in the long run cannot be ensured without the creation of an effective budget management system. An innovative tariff policy has been proposed and opportunities for using non-traditional agricultural insurance products have been identified. Recommendations have been made to improve the state's budget and treasury activities. It is substantiated that the budget deficit is an almost constant phenomenon in the economy of every state, in Ukraine it is a chronic phenomenon, the presence of the deficit is indirect for the population, but it participates in the return of the funds involved to cover the deficit through payment of taxes.
\end{abstract}

Key words: Global experience, budget system, mechanism, economic, tax, Budget Code.

JEL Classification: H60, H61, H83

\section{Introduction}

Global experience shows that the long-term dynamic development of states, regions, and communities cannot be ensured without an effective budget management system in place. It is no secret that at present the Ukrainian budget from a purely economic regulator (which by its nature should be) has become an instrument of political manipulation, bidding, on the basis of political discord and a source of corrupt business interests. Excessive centralization of power has not only led to miscalculations in the socio-economic development of the state, but also does not allow it to deal with strategic state issues, since the daily work of the government and people's deputies is to solve many peripheral problems.

Meanwhile, sound orderly budget management is able to provide a coherent system for implementing strategic priorities. Decentralization of power, which has become the leading link in today's

Corresponding author:

${ }^{1}$ Vinnytsia National Agrarian University, Ukraine.

E-mail: natkov@i.ua

ORCID: https://orcid.org/0000-0002-2877-4302

ResearcherID: L-5920-2018 domestic reforms, has actually begun in 2014 with budgetary decentralization.

The budget system of Ukraine, in accordance with Article 5 of the Budget Code of Ukraine, consists of the state budget and local budgets. The local budgets are the budget of the Autonomous Republic of Crimea and regional, district, and local government budgets. Local government budgets are budgets of territorial communities of villages, their associations, settlements, cities (including districts in cities), budgets of integrated territorial communities.

\section{Economic crisis effects on consumer behavior}

Consolidated budget indicators are used to forecast the economic and social development of the state. According to the article of the Budget Code of Ukraine, consolidated budgets are divided into consolidated budget of Ukraine, consolidated 
budget of the Autonomous Republic of Crimea, consolidated budget of the region, consolidated budget of the district, consolidated budget of the city with district division.

Such a structure of the budget system, in which all local administrations are granted the right to have their own budget, provides the most complete account of the sources of budgeting and their rational use. The unity of the budget system is ensured by a single legal basis, the use of a unified budget classification, the unity of forms of budget documentation, the submission of the necessary statistical and budget information from one level of the budget system to another for drawing up the consolidated budget of the territory (district, city, region) and the state as a whole, in accordance with the principles of a budget process, a single monetary system, the creation and operation of a single treasury account and the State Treasury system.

The purpose of the article is to review the budget system of Ukraine and to keep records of changes in its legislation in its budgetary institutions.

\section{Differences in consumer spending behaviour among age groups}

The state budget is the main national centralized fund. With the help of the budget, the state concentrates a certain share of gross domestic product and distributes it centrally to the development of the national economy, for social protection of the population, the maintenance of state authorities and government, and the defense of the country. The state budget for each financial year is considered by the Supreme Council of Ukraine and approved as a law.
The budget system of Ukraine, in accordance with Article 7 of the Budget Code of Ukraine, is based on the following principles:

- Unity - The unity of the budget system of Ukraine is ensured by a single legal framework, a single monetary system, a single regulation of budgetary relations, a single budgetary classification, the unity of the order of budget execution and accounting and reporting;

- Balance - Budget spending authority should be consistent with the amount of budget revenue for the relevant budget period;

- Independence - The state budget of Ukraine and local budgets are independent. The state does not bear responsibility for the budgetary commitments of the authorities of the Autonomous Republic of Crimea and bodies of local self-government through the funds of the state budget;

- Completeness - All budget receipts and expenditures of budgets, which are carried out in accordance with the normative-legal acts of state authorities, authorities of the Autonomous Republic of Crimea, bodies of local selfgovernment, shall be included in the composition of budgets;

- Justification - The budget is formed on the basis of realistic macroeconomic indicators of economic and social development of Ukraine and estimates of budget revenues and budget expenditures, which are carried out in accordance with approved methods and rules;

- Efficiency and effectiveness - In budgeting and implementation, all budgetary actors should strive to achieve the goals set on the basis of the national value system and the objectives of innovative

Table 1

Implementation of the state budget of Ukraine in 2019 (million UAH)

\begin{tabular}{|l|c|c|c|c|}
\hline \multicolumn{1}{|c|}{2019} & Income & Costs & Lending & Balance (budget deficit) \\
\hline Scheduled indicators & 1026131.8 & 1112130.0 & 3991.1 & -89989.3 \\
\hline January & 54550.7 & 65817.4 & 667.5 & -11934.1 \\
\hline February & 124770.7 & 138487.4 & -8.6 & -13708.1 \\
\hline March & 210623.7 & 237399.5 & -609.7 & -26166.1 \\
\hline April & 322564.1 & 324801.7 & -518.9 & -1718.7 \\
\hline May & 426720.6 & 420436.3 & -1370.3 & 7654.6 \\
\hline June & 506849.3 & 508564.9 & -844.0 & -871.6 \\
\hline July & 584137.1 & 586490.6 & 503.6 & -2857.1 \\
\hline August & 671795.9 & 668895.4 & 515.2 & -20675.1 \\
\hline September & 739751.0 & 758748.1 & 1678.0 & -30278.2 \\
\hline October & 810914.9 & 839569.9 & 1623.1 & -34860.1 \\
\hline November & 899707.3 & 933450.6 & 1116.7 & -78049.5 \\
\hline December & 998278.9 & 1072891.5 & 3437.0 & \\
\hline
\end{tabular}

* the values of indicators by months (income, expenses, crediting) are provided with a growing result

* Scheduled metrics as of January 1, 2019, excluding budget adjustments for the year 
development of the economy by providing quality services;

- Subsidiarity - Allocation of types of expenditures between the state budget and local budgets, as well as between local budgets, is based on the need to maximize the approximation of guaranteed services to their direct customers;

- Purposeful use of budgetary resources Budgetary funds are used only for the purposes defined by budgetary appropriations and budgetary allocations;

- Justice and impartiality - Ukraine's budget system is based on a just and impartial distribution of social wealth between citizens and territorial communities;

- Publicity and transparency - Informing the public on drafting, reviewing, approving, implementing the state budget and local budgets, as well as monitoring the implementation of the state budget and local budgets.

In order to ensure full and timely receipt of revenues and the use of appropriations for the intended purpose, the proper organization of accounting of the execution of the budget is necessary.

Accounting for the execution of the budget and the estimates of budgetary institutions is called budgetary accounting.

The objects of budget accounting are:

- budget revenues and expenditures;

- cash in banks;

- funds in calculations between budgets;

- funds and reserves created in the process of budget execution;
- material values of budgetary institutions, etc.

The budgetary account promotes the rational distribution of national income for the purpose of expanded reproduction and the achievement and maintenance of the necessary proportions in the development of certain sectors of the national economy, accurate execution of the approved budget.

The tasks of budget accounting are:

- control over the exact implementation of the approved budget;

- adherence to fiscal discipline and the most stringent economy of spending on budget spending; - ensuring the safety of property, state property;

- identifying additional revenue and mobilizing funds into the budget.

The budgetary account is kept in accordance with the current budget system in Ukraine. The budget execution is assigned directly to the State Treasury Service established within the Ministry of Finance of Ukraine. The Unified Treasury Management System consists of the General Directorate and its subordinate bodies. The regional bodies of the state treasury department are composed of district and inter-district offices.

The bodies of the State Treasury Department are entrusted with the following tasks:

- organization, implementation and control of the execution of the state budget of Ukraine, management of revenues and expenditures of this budget, based on the principle of a single treasury account;

- regulation of financial relations between the state budget and state extrabudgetary funds, financial

Table 2

Execution of the state budget of Ukraine from 2008 to 2019 (million UAH)

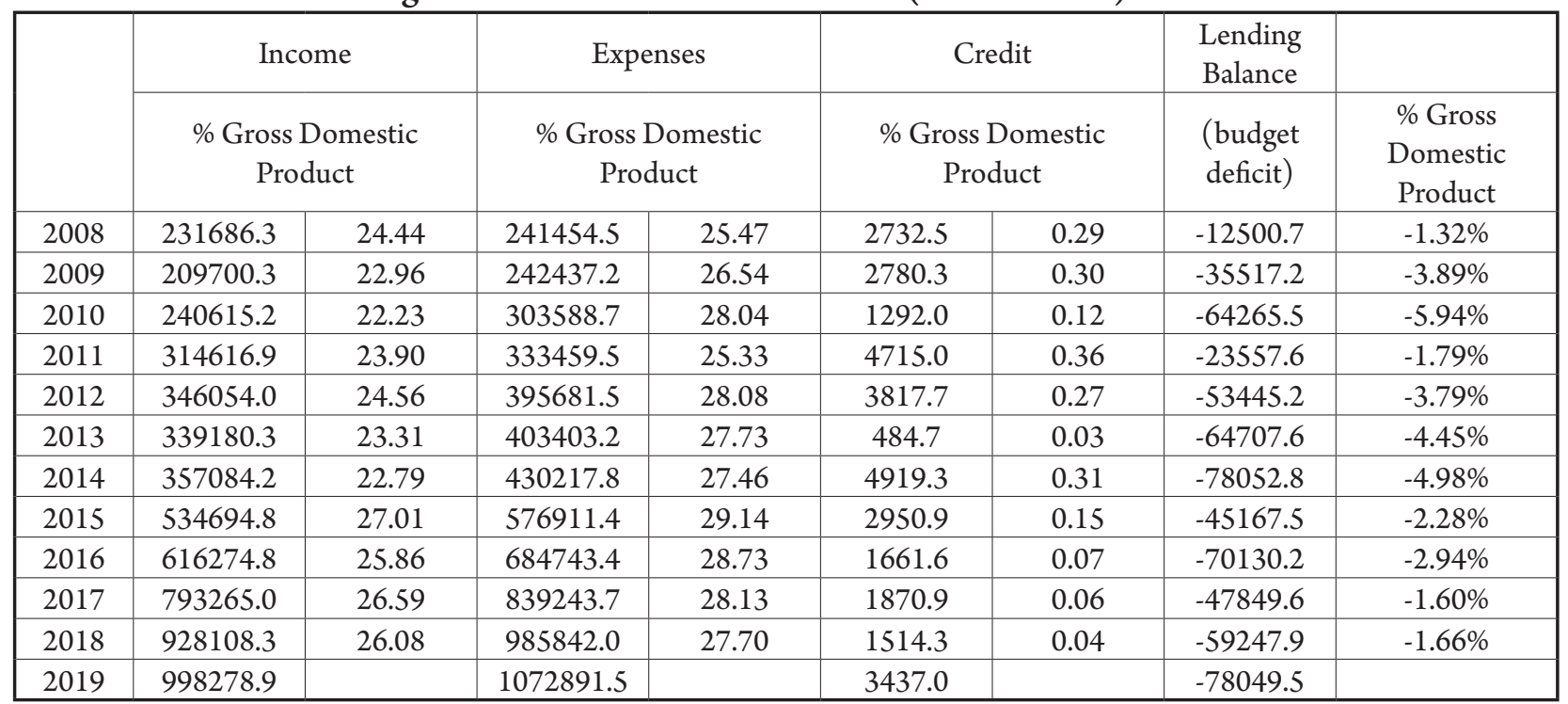


implementation of these funds, control over the receipt and use of extrabudgetary funds;

- implementation of short-term forecasting of public financial resources, as well as operational management of these resources within the limits of the established state expenditures;

- collecting, processing and analyzing information on the state of public finances and the budget system of the country;

- development of methodological and instructional materials, accounting procedures in budgetary institutions, development of budget classification, etc.

The Main Department of the State Treasury Department organizes and implements a consolidated, systematic, complete and standardized accounting of operations on the movement of fundsfrom the state budget of Ukraine, state extrabudgetary funds and extrabudgetary funds in the Treasury accounts; develops and approves methodological and guidance materials; establishes the procedure for accounting and reporting on the implementation of the budgetary institutions' estimates.

Accounting in budgetary institutions provides a reflection of all operations related to the implementation of the budget expenditures, estimates of special funds and summarization of accounting and reporting necessary for the operational management, analysis, control over the targeted use of funds on the basis of estimates, the detection of unplanned and illegal costs. For this purpose, there are kept the records of:

loans (appropriations) and expenditures of budgetary funds;

receipt and spending of special funds;

preservation and efficiency of the use of cash, tangible assets, equipment, food, medicines and other valuables;

settlements with debtors and creditors, including payroll.

Accounting for the implementation of estimates of revenues and expenditures in budgetary institutions is maintained by a dual system, by memorial-warrant, journal-warrant, journal-head or computerized form of accounting.

The accounting of the implementation of the estimates of general and special funds in budgetary institutions is maintained on a single balance sheet under a single plan of accounts. But if the budgetary institutions have large subsidiary production (training) workshops or auxiliary agricultural and research farms, transferred to economic calculation (have an independent balance sheet and bank accounts), then the latter organize and maintain accounting in accordance with the plan of accounts of industrial enterprises (industrial, agricultural, etc.).

The head of the institution and the chief accountant are responsible for the observance of the rules of budgetary discipline and the proper organization of accounting in budgetary institutions. The Chief Accountant shall be guided by the Law of Ukraine "On Accounting and Financial Reporting in Ukraine" dated 16.07.1999 No. 996-XIV, other normative acts of the higher bodies of state power and management, instructions and instructions of the SCU. These documents define the responsibilities, rights of the chief accountant for the correct organization of accounting, which apply to employees of accounting services of all enterprises, institutions and organizations, regardless of ownership and forms of management.

The tasks of the accounting department of the institutions are:

1. organization of accounting in accordance with the current regulatory documents;

2. introduction of advanced forms and methods of accounting work and processing of accounting documents using modern computer technology and related software;

3. carrying out preliminary control over timely, correct registration of documents and legality, expediency of performed operations;

4. control of correctness, rationality, economy of spending of funds in accordance with open financing and their purpose;

5. strict control over rational and economical use of material, labor and financial resources, fight against mismanagement and waste, prevention of such negative phenomena;

6. timely financing of self-sustaining institutions, control over their activities and accounting in these institutions;

7. ensuring the accounting of revenues and expenditures at special and other extrabudgetary funds;

8. timely identification and prevention of negative phenomena in economic and financial activities, identification and mobilization of intra-economic reserves for improving resource use and financing;

9. formation and timely submission of necessary information for internal management and for external users (suppliers, customers, bank, tax, treasury, etc.); 
10. timely accrual and payment of salaries, scholarships, allowances, pensions, etc.;

11. accounting and control of the state of payments for salaries, scholarships, as well as with other debtors and creditors;

12. participation in the inventory and timely and correct registration of its results;

13. periodic Instruction of materially responsible persons (MRPs) on the issues of accounting and maintenance of inventory, funds that are in their responsible storage;

14. drawing up the report and submitting it to the relevant authorities within the established terms, ensuring the accuracy, completeness and objectivity of the reporting data and balances;

15. adherence to the established procedure for keeping accounting documents, accounting records, estimates and calculations thereto; timely preparation and transfer to the archive, etc.

\section{Findings}

The chief accountant of an institution, central accounting, is appointed or dismissed by the head of the institution and reports directly to him/her. He/ she provides control over all business operations and their reflection in accounting, preparation and timely submission of financial statements, signs (together with the manager) documents on financial and settlement operations, on the issuance of inventory, money, etc. If the employees of the institution submit to the chief accountant documents for operations that contradict the law or violate contracts, agreements, financial discipline, the chief accountant is obliged to notify the head of the institution in writing. Having received from the manager a written order to execute the said documents, the chief accountant executes it. At the same time, the responsibility for carrying out illegal operations rests with the head of the institution. The Chief Accountant vis-à-vis applications, orders for the appointment and transfer of MRPs (head of warehouses, storekeepers, cashiers, etc.), agreements, contracts, contracts for the execution of works, supply of inventory, etc.

The chief accountant of a budgetary institution for alleged misconduct in professional activity may be held liable under the current legislation.

At the dismissal of the chief accountant, the state of accounting and truthfulness, reliability of reporting, availability of accounting documents and accounting registers, files in the archive, etc., should be carried out. The transfer of cases to the newly appointed chief accountant is made on the basis of a special act of acceptance-transfer, which is approved by the head of the institution.

\section{Conclusions}

Thus, if budget revenues exceed expenditures, this is called budget surplus; but if the budget expenditures exceed its revenue, it is called a budget deficit. Budget deficits caused by declining budget revenues and rising budget expenditures are one of the main drivers of inflation. The state budget revenues in Ukraine are generated mainly through various taxes and fees, as well as some other sources, in particular, from the privatization of state property.

Budget deficits are a phenomenon almost constant in the economy of every state. In particular, this phenomenon is chronic in Ukraine. For the population, the existence of a deficit is indirect, but it participates in the return of the funds involved to cover the deficit by paying taxes. The budget deficit is usually estimated as a percentage of GDP.

According to the results of 2019, revenues of the General Fund of the State Budget increased by $5.5 \%$ to 879.8 billion UAH. These are the latest data from the State Treasury on the preliminary results of fiscal year of 2019. The Treasury has prepared an appropriate commentary on the closure of fiscal year of 2019: operational data.

As a result of the year, the Government has fully funded the necessary protected items of expenditure and a number of other expenditures that contribute to the development of the economy and the well-being of citizens. For the first time in the last 5 years, the government borrowing plan has been fully implemented, which was made possible by an effective public debt management policy.

In 2019, the Treasury Department approved the 2020 budget timetable in advance. It also identified a list of 114 budget programs under which the main spending units should prepare or amend the procedures for the use of funds for the timely and effective financing of budget programs. The chief spending units will have to approve passports of budget programs with quality indicators of efficiency and effectiveness by February 15, which the Finance Ministry has already emphasized to the top spending units. From the first working day of 2020, the SCSU begins to finance budgetary programs, and therefore all authorities continue to work together to ensure the smooth financing of budgetary commitments. 
Regarding accounting in budgetary institutions, the Cabinet of Ministers of Ukraine made changes. According to the results of 2019, revenues of the General Fund of the State Budget increased by $5.5 \%$ to 879.8 billion UAH. These are the latest data from the State Treasury on the preliminary results of fiscal year of 2019. As a result of the year, the Government has fully funded the necessary protected items of expenditure and a number of other expenditures that contribute to the development of the economy and the well-being of citizens. According to SCSU operational data, the total deficit was less than planned and amounted to 81.2 billion UAH (which is estimated at about $2.0 \%$ of GDP). In particular, the deficit of the General Fund of the State Budget was within the target of 69 billion UAH.

For the first time in the last 5 years, the government borrowing plan has been fully implemented, which was made possible by an effective public debt management policy.

In 2019, the Treasury Department approved the 2020 budget timetable in advance. It also identified a list of 114 budget programs under which the main spending units should prepare or amend the procedures for the use of funds for the timely and effective financing of budget programs. The chief spending units will have to approve passports of budget programs with quality indicators of efficiency and effectiveness by February 15, as the Ministry of Finance has already emphasized to the top spending units. From the first working day of 2020, the SCSU begins to finance budgetary programs, and therefore all authorities continue to work together to ensure the smooth financing of budgetary commitments. The State Treasury has switched to IBAN accounts.

From January 1, 2020, the State Treasury Service of Ukraine (hereinafter referred to as the Treasury) switched to accounting under the Public Sector Accounting Account Plan, approved by Order of the Ministry of Finance of Ukraine dated December 31, 2013 No. 1203, as amended (hereinafter - Account Plan No. 1203). From January 1, 2020, new bills for taxation, fees, payments to the state and local budgets, accounts for electronic VAT administration system, electronic fuel and alcohol sales administration system, bills for crediting the single contribution to the obligatory state social Customs authorities' insurance and deposit accounts, own-account opened under the Accounts Plan No.1203, taking into account the IBAN International Bank Account Number of 29, as required by the National Bank of Ukraine dated December 28, 2018 No. $162 \ll$ On Introduction of International Bank Account Number (IBAN) in Ukraine" (as amended).

Please, note that the accounts that were opened under the State and Local Budget Execution Accounts Plan approved by the Decree of the State Treasury of Ukraine No. 119 dated November 28, 2000 (hereinafter - Accounts Plan No. 119) are closed from January 1, 2020.

\section{References:}

Budget Code of Ukraine dated 30.08.2010.

Resolution of the Board of the National Bank of Ukraine dated December 28, 2018 No. 162 "On Introduction of the International Bank Account (IBAN) in Ukraine" (as amended).

Law of Ukraine On accounting and financial reporting in Ukraine As amended by Laws of Ukraine of May 11, 2000 No. 1707-III, of June 8, 2000 No. 1807-III, dated June 22, 2000 No. 1829-III.

Aleskerova, Yu., Mulyk, T., \& Fedoryshyna, L. (2018). Improving credit protection analysis methods Reports of main agricultural enterprises. Baltic Journal of Economic Studies, vol. 4, no. 2, pp. 1-7. doi: $10.30525 / 2256-0742 / 2018-4-2-1-7$

Aleskerova, Yu., \& Fedoryshyna, L. (2018). Analysis of investment activities of enterprises of Ukraine. Economic system development trends: the experience of countries of Eastern Europe and prospects of Ukraine.

Aleskerova, Yu., Fedoryshyna, L., \& Koval, N. (2018). Features of loan security for the reproduction of fixed assets for agricultural purposes. Baltic Journal of Economic Studies, vol. 4, no. 4, pp. 1-5. doi: $10.30525 / 2256-0742 / 2018-4-4-1-5$

Aleskerova, Y., Kovalenko, L., \& Havryliuk, V. (2019). Innovative financial criteria for methodological approaches to the assessment of agrarian insurance. Baltic Journal of Economic Studies, vol. 5, no. 4, pp. 34-41. doi: 10.30525/2256-0742/2019-5-4-34-41

Rogach, S., Vdovenko, L., \& Polishchuk, O. (2019). Agriculture of Ukraine under the joint policy of the European Union. Baltic Journal of Economic Studies, vol. 5, no. 3, pp. 178-183. doi: 10.30525/22560742/2019-5-3-178-183 
Vol. 1, No. 1, 2020

Plakhtii, T., Fedoryshyna, L., \& Tomchuk, O. (2019). Socio-economic component of preferential taxation of individuals' incomes. Baltic Journal of Economic Studies, vol. 5, no. 2, pp. 171-175. doi: 10.30525/22560742/2019-5-2-171-175

Koval, N., Priamuhina, N., \& Zhmurko, I. (2020). Analyz economic - financial experience of the world countries in the system of pension insurance. Baltic Journal of Economic Studies, vol. 6, no. 1, pp. 1-7. doi: 10.30525/2256-0742/2020-6-1-1-8

Kritzer, B. E. (1996). Privatizing social security: the Chilean experience. Social Security Bulletin, no. 3, pp. 45-55.

Kubicek (2005). Contribution rates to funded pension systems in the new member countries. Research in International Business and Finance, vol. 19, issue 2, pp. 266-280.

Bettendorf, Leon J.H. \& Heijdra, Ben J. (2005). Population ageing and pension reform in a small open economy with non-traded goods. Journal of Economic Dynamics Control, no. 6, pp. 265-290.

Nicoholas George (2002). Sweden's savers are kept pasted on state of their funds. Financial Times. 2002. March 25, p. 7.

Oskar Cerrangolo (2003). Pension Reform in Latin America. Conference on «Privatisation of Public Pension Systems - Forces, Experience, Prospects». Vienna, 2003. June 19-21, pp. 256-275.

Palmer Edvard (1998). The Swedish Pension Reform Model - Framework and Issues.The national Social Insurance Board, May. 32 p. 